\title{
Regenerative Medicine and Tissue Engineering: How Far Are We?
}

\section{Raymund E Horch ${ }^{1,3 *}$, Aldo Boccaccini ${ }^{2,3}$ and Andreas Arkudas ${ }^{1,3}$}

${ }^{1}$ Department of Plastic and Hand Surgery and Laboratory of Tissue Engineering and Regeneration Medicine, University Hospital Erlangen, Friedrich Alexander University of Erlangen-Nuernberg

${ }^{2}$ Institute of Biomaterials at the Department of Materials Science and Engineering, Friedrich Alexander University of Erlangen-Nuernberg

${ }^{3}$ Emerging Fields Initiative TopBiomat, Friedrich Alexander University of Erlangen-Nuernberg

When the term 'Tissue Engineering' (TE) was first coined and propagated enthusiasm was great among researchers, clinicians and the public that soon any part of the human organism could be replaced if all efforts would be undertaken to bring the ingenious visions from the first hours into existence [1].

Many fields have emerged that show how continuous research offers steadily new perspectives when problems are addressed in a stringent way. One of these examples is the investigation of extrinsic and intrinsic vascularization of matrices and (neo)-angiogenesis of constructs, because still the vascular supply of TE products remains one major barrier to successful and routine clinical translation. Although many insights can be gained from in vitro testings, and in vivo research in small animals is a splendid way to elucidate principal mechanisms, the translation into large animal models is one necessary step to further advance TE and Regenerative Medicine (RM). One should be aware of the fact that - similar to drug development - finally the true outcome in the human organism is what will help our patients to regain lost tissue and functions without the price of side effects or donor site morbidity.

Without doubt the collaboration of scientists from many various disciplines has led to the development of a multitude of brilliant inventions, latest research tools and scientific techniques which are now constantly incorporated in this yet growing scientific field $[2,3]$.

The stem cell arena has opened many more fascinating future prospects for the regeneration or reconstitution of lost tissue and organ functions. Once we learn more about the nature of modulating growth and differentiation of mesenchymal stem cells or potentially reprogrammed cells we could overcome many hurdles in Regenerative Medicine that we tackle with at the moment. The Nobel Prize that was recently awarded to the Japanese scientist Shinya Yamanaka for discovering the potential of cellular reprogramming with induced pluripotent stem cells (IPC) - despite there is no clinical translation in sight at the very moment now - shows how high the estimates of potential possibilities are with regard to this new field. Nevertheless, the whole stem cell research is still in the early phase, while a few therapies that are based on tissue engineering concepts have already successfully entered the clinical stage [4-6].

Meanwhile we will have to focus on the evolution of that what has been achieved so far. That means that we should strive to optimize culture conditions of cells in any thinkable aspect (culture media, $3 \mathrm{D}$ cultures, flow through reactors, multi-mixed cell-culture systems etc.) and propagate methods that will lead to an optimal performance of products from TE and RM [6]. One example is the combination of microsurgical or supermicrosurgical methods [7] together with basic science techniques, such as the creation of arterio-venous loops to prevascularize constructs (Figure 1) before they can be successfully transplanted into organisms [3,8-11]. In a 12 week study in the sheep AV-loop model de novo engineering of independently axially vascularized transplantable bone tissue in clinically significant amounts was shown, when directly autotransplanted MSCs and rhBMP-2 stimulation had been used [10]. Combining such efforts is also beginning to show results when targeting complex functional organs, such as liver bioreactors $[12,13]$.

It seems also logical to expand the methodological possibilities of TE and RM [6] to more common fields in research and medicine, that could benefit from new research pathways. For instance the field of cancer development and investigations into tumor dissemination, progression and blocking is an ideal playground for the application of cell science and TE methods, as has previously been reported [14]. Once again the arterio-venous loop model in isolated chambers implanted into experimental settings could reveal basic mechanisms of tumorigenesis and metastasis formation [15]. On the way to seek new solutions new cell types have been found more or less by serendipity, such as Telocytes, that could play a crucial role in opening more hitherto unknown horizons of harnessing the power of regeneration [16-19] (for further information see http://www.telocytes.com).

Not at least, to further our funding sources and enhancing public

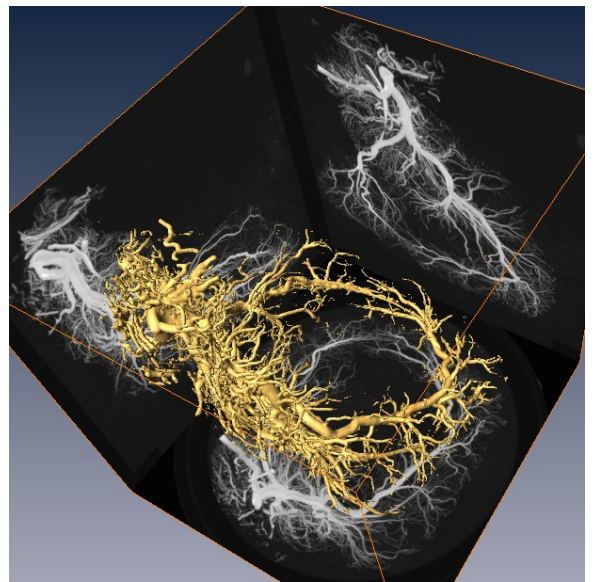

Figure 1: Micro-CT scanning of vascular outgrowth and sprouting from an arteriovenous loop in a tissue engineered construct four weeks after implantation using VEGF165 and bFGF.

*Corresponding author: Dr. Raymund E Horch, Director and Chairman Department of Plastic and Hand Surgery and Laboratory of Tissue Engineering and Regeneration Medicine, Friedrich Alexander University of ErlangenNuernberg, Germany, Tel: 091318533 277; Fax: 091318539 327; E-mail: Raymund.Horch@uk-erlangen.de

Received February 25, 2013; Accepted February 26, 2013; Published February 28,2013

Citation: Horch RE, Boccaccini A, Arkudas A (2013) Regenerative Medicine and Tissue Engineering: How Far Are We? J Tissue Sci Eng 4:e121. doi:10.4172/21577552.1000e121

Copyright: ( 2013 Horch RE, et al. This is an open-access article distributed under the terms of the Creative Commons Attribution License, which permits unrestricted use, distribution, and reproduction in any medium, provided the original author and source are credited. 
Citation: Horch RE, Boccaccini A, Arkudas A (2013) Regenerative Medicine and Tissue Engineering: How Far Are We? J Tissue Sci Eng 4:e121. doi:10.4172/2157-7552.1000e121

support we need to make clear that TE and RM are not hazardous Frankenstein like endeavours but are soundly controlled by the scientific community. Therefore ethical issues with the use of embryonic stem cells or the use of animals have to be discussed and should be clearly answered with regard to clinical translation [20]. The effort of concentrating funding means and joining forces by institutions into so called "high-risk but high potential future research projects" is one way to overcome the momentary stagnation of traditional funding sources. As an example in the Friedrich Alexander University of Erlangen Nuernberg for instance the President and his taskforce have evoked a program of Emerging Field Initiatives (EFI) that allows a dedicated group of scientists from different faculties to set up an interdisciplinary working group where material scientists [21-24] and cell biologists can team up with various clinical scientists (for further information see: http://www.efi.uni-erlangen.org/projects/topbiomat/). Such instruments to substitute highly innovative areas of research that would otherwise not be funded by industry or by traditional public funding institutions are one way to bring the field forward.

\section{Conclusion}

In summary it can be stated that if all efforts in material science, cellular and molecular biology, gene techniques, cell programming, together with sound clinical expertise are brought together we will see that TE and RM through such interdisciplinary approaches might become a part of clinical routine in the near future.

We want to thank the Xue Hong and Hans Georg Geis Stiftung for their continuous support of biomedical research in Tissue Engineering and Regenerative Medicine.

When it is obvious that the goals cannot be reached, don't adjust the goals, adjust the action steps.

"Confucius"

\section{References}

1. Vacanti CA (2006) The history of tissue engineering. J Cell Mol Med 10: 569576 .

2. Vacanti $J(2010)$ Tissue engineering and regenerative medicine: from first principles to state of the art. J Pediatr Surg 45: 291-294.

3. Horch RE, Kneser U, Polykandriotis E, Schmidt VJ, Sun J, et al. (2012) Tissue engineering and regenerative medicine -where do we stand? J Cell Mol Med 16: 1157-1165.

4. Horch RE, Kopp J, Kneser U, Beier J, Bach AD (2005) Tissue engineering of cultured skin substitutes. J Cell Mol Med 9: 592-608.

5. Horch RE (2010) Tissue engineering in plastic and reconstructive surgery. Handchir Mikrochir Plast Chir 42: 327-328.

6. Polykandriotis E, Schmidt VJ, Kneser U, Jianming S, Boccaccini AR, et al (2012) Bioreactors in regenerative medicine--from a technical device to a reconstructive alternative?. Handchir Mikrochir Plast Chir 44: 198-203.

7. Taeger CD, Horch RE, Dragu A, Beier JP, Kneser U (2012) [Perforator flaps. A new era in reconstructive surgery]. Chirurg 83: 163-171.

8. Rath SN, Arkudas A, Lam CX, Olkowski R, Polykandroitis E et al. (2012) Development of a pre-vascularized 3D scaffold-hydrogel composite graft using an arterio-venous loop for tissue engineering applications. J Biomater Appl 27 : 277-289.

9. Rath SN, Pryymachuk G, Bleiziffer OA, Lam CX, Arkudas A, et al. (2011) Hyaluronan-based heparin-incorporated hydrogels for generation of axially vascularized bioartificial bone tissues: in vitro and in vivo evaluation in a PLDLLA-TCP-PCL-composite system. J Mater Sci Mater Med 22: 1279-1291.
10. Boos AM, Loew JS, Deschler G, Arkudas A, Bleiziffer O, et al. (2011) Directly auto-transplanted mesenchymal stem cells induce bone formation in a ceramic bone substitute in an ectopic sheep model. J Cell Mol Med 15: 1364-1378.

11. Boos AM, Loew JS, Weigand A, Deschler G, Klumpp D, et al. (2012) Engineering axially vascularized bone in the sheep arteriovenous-loop model. $\mathrm{J}$ Tissue Eng Regen Med.

12. Erro E, Bund J, I M, Chalmers SA, Gautier A (2013) Bioengineering the Liver: Scale-Up and Cool Chain Delivery of the Liver Cell Biomass for Clinical Targeting in a Bioartificial Liver Support System. Biores Open Access: 2.

13. Horch RE (2012) New Developments and Trends in Tissue Engineering: An Update. J Tissue Sci Eng 3: e110.

14. Hutmacher DW, Horch RE, Loessner D, Rizzi S, Sieh S, et al. (2009) Translating tissue engineering technology platforms into cancer research. J Cell Mol Med 13: $1417-1427$.

15. Bleiziffer O, Hammon M, Naschberger E, Lipnik K, Arkudas A, et al. (2011) Endothelial progenitor cells are integrated in newly formed capillaries and alter adjacent fibrovascular tissue after subcutaneous implantation in a fibrin matrix. J Cell Mol Med 15: 2452-2461.

16. Cretoiu SM, Cretoiu D, Marin A, Radu BM, Popescu LM (2013) Telocytes: ultrastructural, immunohistochemical and electrophysiological characteristics in human myometrium. Reproduction.

17. CreÅ£oiu SM, CreÅ£oiu D, Popescu LM (2012) Human myometrium - the ultrastructural 3D network of telocytes. J Cell Mol Med 16: 2844-2849.

18. Gherghiceanu M, Popescu LM (2012) Cardiac telocytes - their junctions and functional implications. Cell Tissue Res 348: 265-279.

19. Popescu LM, Manole E, Serboiu CS, Manole CG, Suciu LC, et al. (2011) Identification of telocytes in skeletal muscle interstitium: implication for muscle regeneration. J Cell Mol Med 15: 1379-1392.

20. Horch RE, Pepescu LM, Vacanti C, Maio G (2008) Ethical issues in cellular and molecular medicine and tissue engineering. J Cell Mol Med 12: 1785-1793.

21. Yunos DM, Ahmad Z, Salih V, Boccaccini AR (2013) Stratified scaffolds for osteochondral tissue engineering applications: electrospun PDLLA nanofibre coated Bioglass(R)-derived foams. J Biomater Appl 27: 537-551.

22. Vargas GE, Haro Durand LA, Cadena V, Romero M, Mesones RV, et al. (2013) Effect of nano-sized bioactive glass particles on the angiogenic properties of collagen based composites. J Mater Sci Mater Med

23. El-Gendy R, Yang XB, Newby PJ, Boccaccini AR, Kirkham J (2013) Osteogenic Differentiation of Human Dental Pulp Stromal Cells on 45S5 Bioglass(®) Based Scaffolds In Vitro and In Vivo. Tissue Eng Part A 19: 707-715.

24. Arkudas A, Balzer A, Buehrer G, Arnold I, Hoppe A, et al. (2013) Evaluation of Angiogenesis of Bioactive Glass in the Arteriovenous Loop Model. Tissue Eng Part C Methods. 